\title{
Phase Preference by Active, Acetate-Utilizing Bacteria at the Rifle, CO Integrated Field Research Challenge Site
}

\author{
Lee J. Kerkhof ${ }^{1^{*}}$, Kenneth H. Williams ${ }^{2}$, Philip E. Long ${ }^{3}$, Lora R. McGuinness ${ }^{1}$ \\ ${ }^{1}$ Institute of Marine and Coastal Science, Rutgers University, Rutgers University, 71 Dudley Rd., New \\ Brunswick, NJ 08901-8521; ${ }^{2}$ Lawrence Berkeley National Laboratory, Berkeley, CA; ${ }^{3}$ Pacific \\ Northwest National Laboratory, Richland, WA. \\ E-mail: lkerkhof@rutgers.edu.
}

ABSTRACT. Previous experiments at the Rifle, Colorado Integrated Field Research Challenge (IFRC) site demonstrated that field-scale addition of acetate to groundwater reduced the ambient soluble uranium concentration. In this report, sediment samples collected before and after acetate field addition were used to assess the active microbes via ${ }^{13} \mathrm{C}$ acetate stable isotope probing on 3 phases [coarse sand, fines (8-approximately 150 micron), groundwater (0.2-8 micron)] over a 24 -day time frame. TRFLP results generally indicated a stronger signal in ${ }^{13} \mathrm{C}$-DNA in the "fines" fraction compared to the sand and groundwater. Before the field-scale acetate addition, a Geobacter-like group primarily synthesized ${ }^{13} \mathrm{C}$ DNA in the groundwater phase, an alpha Proteobacterium primarily grew on the fines/sands, and an Acinetobacter sp. and Decholoromonas-like OTU utilized much of the ${ }^{13} \mathrm{C}$ acetate in both groundwater and particle-associated phases. At the termination of the field-scale acetate addition, the Geobacter-like species was active on the solid phases rather than the groundwater while the other bacterial groups had very reduced newly synthesized DNA signal. These findings will help to delineate the acetate utilization patterns of bacteria in the field and can lead to improved methods for stimulating distinct microbial populations in situ.

KEYWORDS. uranium reduction; stable isotope probing; active bacteria; sediment-associated microbes 


\section{Introduction:}

Research at the Integrated Field-Scale Subsurface Research Challenge Site (IFRC) at Rifle, Colorado addresses knowledge gaps in understanding the mechanisms and rates of U(VI) bioreduction in alluvial sediments. For example, a 3-month bio-stimulation experiment was initiated in 2002 that stimulated in situ uranium reduction in the field (1). Characterization of the bacteria during this experiment from groundwater indicated Geobacter-like microbes dominated up to $80 \%$ of the clones in SSU libraries during the first 20 days of stimulation. These Geobacter-like clones were found to diminish as the system approached sulfate reduction during continued acetate amendment (1). Likewise, a similar injection experiment in 2003, replicated uranium reduction during biostimulation with enrichment of Geobacter-like clones in groundwater (approx 75\%) and sediment samples (<10\%), suggesting differences between microbial populations in groundwater and soil particles (2). These reports indicated that Geobacter-like microbes responded positively to acetate utilization and may be important in uranium reduction. However, the presence/absence of a particular SSU rRNA gene sequence in an environmental sample does not conclusively demonstrate that the particular microorganism is active or crucial in any biogeochemical process at the time of sampling. Furthermore, multiple questions remain including: A) which microorganism(s) are consuming this acetate at Rifle, B) can changes in activity patterns in sediment associated bacteria be observed after field-scale acetate addition, and C) do active microorganisms demonstrate a preference for phase (either sand associated, fines associated, or planktonic in the groundwater?

In order to address these issues and elucidate the active bacteria involved in acetate utilization at Rifle, stable isotope probing (SIP) methods were applied to determine those microbe(s) which could use

${ }^{13} \mathrm{C}$ acetate to replicate their genomes in microcosms incubated from 1-24 days. For example, stable isotope incorporation into macromolecules from environmental samples has been used to target metabolically active bacteria by monitoring phospholipids (3, 4, 5) This principle of purifying isotopically-labeled nucleic acids and coupling to molecular ecology techniques was presented by 
Radajewski et al., using ${ }^{13} \mathrm{C}$-methanol to identify the active degraders in soil samples (6). Similar studies using the SIP techniques have been applied to a variety of natural systems using substrates ranging from methanol, methyl bromide, phenol, naphthalene, phenanthrene, benzoate, and salicylate (7, 8, 9).

During the summer of 2007, another acetate field-scale amendment was initiated at Rifle and found to significantly reduce uranium groundwater concentrations to below the regulatory drinking water standards $(<0.137 \mu \mathrm{M})$. This field study (aka. the Winchester experiment) was designed to replicate the dominance by Geobacter sp. in groundwater from prior studies during biostimulation (10). Therefore, SIP microcosm experiments were initiated with freshly drilled alluvial soil samples both before and after field biostimulation with acetate to determine if changes in active bacterial profiles could be observed. In order to ascertain if the acetate-utilizing bacteria demonstrated a preference for being sediment-associated or free-living, 3 different phases were operationally defined to determine whether particles harbored different ${ }^{13} \mathrm{C}$ labeled bacterial DNA than groundwater. The fractions (coarse sand, fines, and planktonic) were obtained by settling or filtration onto 8.0 or 0.2 micron filters. The findings indicated multiple groups of bacteria were using the carbon from acetate initially, that specific bacteria prefer being planktonic or particle attached for growth, that changes in bacterial behavior are observed during the field scale addition of electron donor, and that the "fines" contained the largest ${ }^{13} \mathrm{C}$ DNA signal. Ultimately, these types of studies, promoting natural and enhanced uranium bioremediation in the field, should lead to an improved understanding of geomicrobiological systems and predictive reactive transport models which can aid DOE site managers in determining policy to protect watersheds and human health.

\section{Material and Methods:}

Field site. For the 2007 Winchester field experiment (10) an injection/monitoring gallery of 22 wells (2-4 inch) was established in June of 2007 (Figure 1). This gallery configuration was designed to provide uniform acetate concentrations $(<10 \mathrm{mM}$ ) in situ for a period of 30-35 days (Aug 1-Sept 1, 
2007) by cross-well mixing (11). Acetate was added in a double pulse (separated by an unamended groundwater addition) and groundwater samples were collected from all monitoring/ upstream wells in the gallery twice per week and analyzed for electron donor concentration, U(IV) (labile and total), Fe(II), as described in $(1,10)$. The before-field addition sediment samples for SIP were collected during injection gallery/well installation on June, 2007 from wells DO2, DO3. The post-acetate amendment samples were collected in October, 2007 from wells P101 and P102 (Figure 1). The alluvial sediments used in these experiments came from 2 depths for each core (i.e. 4, 5, or $6 \mathrm{~m}$ ). Unfortunately, the cores are generally filled with cobbles and it was often difficult to obtain material that could be placed in serum vials to conduct activity experiments from all depths for any one particular core.

Activity Determination. SIP experiments were performed by filter sterilizing upstream groundwater and overfilling $60 \mathrm{ml}$ serum vials to minimize oxygen contamination. A sample of freshly collected sediment (5-6 g) from wells DO2, DO3, P101 and P102 was then added with $1 \mathrm{mM}{ }^{13} \mathrm{C}$ acetate. The vials were capped, shaken, and allowed to incubate at room temperature for 1, 5, and 24 days. Control additions included $1 \mathrm{mM}{ }^{12} \mathrm{C}$ acetate. After the incubation, each vial was shaken again and destructively sampled. Sand and coarse particles were collected within the SIP incubation vials by allowing a 1-hour settling period after shaking. Fines and silts were obtained by collecting this supernatant after settling with a pipette and concentrating on an $8.0 \mu \mathrm{m}$ filter. Planktonic bacteria within the vials were collected from the $<8.0 \mu \mathrm{m}$ filtrate using a $0.2 \mu \mathrm{m}$ filter. This approach was necessary since traditional particle size fractionation methods would contaminate the SIP incubations with oxygen and generate artifacts during collection.

DNA purification and SIP Gradients. Genomic DNA from each size fraction was purified by phenol/chloroform methods (12). Separation of ${ }^{12} \mathrm{C}$ and ${ }^{13} \mathrm{C}$ DNA utilized $\mathrm{CsCl}$ gradients with archaeal carrier DNA (100 ng of SIP experimental DNA, 300 ng of ${ }^{12} \mathrm{C}$ and ${ }^{13} \mathrm{C}$-archaeal carrier DNA) as described in (13). This approach yields 2 bands, i.e. a ${ }^{12} \mathrm{C}$ band containing genomic DNA from the resident bacteria present in the original sample and $\mathrm{a}^{13} \mathrm{C}$ band containing newly-synthesized DNA from 
bacteria utilizing carbon from the ${ }^{13} \mathrm{C}$ acetate. Small subunit rRNA genes were then PCR amplified using the universal forward primer 27F (labeled with 6-FAM) and the bacterial-specific primer 1100R on a standard volume of ${ }^{12} \mathrm{C}$ or ${ }^{13} \mathrm{C}$ band for TRFLP analysis. A total of 107 profiles were generated during this study (including ${ }^{12} \mathrm{C}$-acetate and no amendment controls) with 133 OTUs detected in all samples. Cloning was accomplished with a TA cloning kit (Invitrogen) on ${ }^{13} \mathrm{C}$ bacterial SSU amplicons. Specific colonies corresponding to specific TRF peaks were identified in the clone library. The double stranded sequence from these SSU genes was determined by dye terminator chemistry. The reactions were run on a Perkin-Elmer ABI 310 genetic analyzer (ABI, Foster City, CA). Accession

numbers for the various TRFLP peaks are GU943742-45. Control incubations using ${ }^{12} \mathrm{C}$ acetate did not detect any amplifiable bacterial DNA in the ${ }^{13} \mathrm{C}$ carrier band using our priming sets and conditions, demonstrating contamination by ${ }^{12} \mathrm{C}$ bacterial DNA in our ${ }^{13} \mathrm{C}$ carrier bands was below our PCR detection limits (supplemental figure 1).

\section{Results and Discussion:}

Field Site Biogeochemistry. During acetate addition, the down gradient wells of the injection gallery exhibited increases in dissolved Fe(II) concentrations from 20-120 $\mu \mathrm{M}$ when experiencing acetate amendment, consistent with iron reduction as a terminal electron sink (Fig. 2). The highest concentrations of dissolved Fe(II) were in the first D01-D04 wells, nearest the injection gallery (data not shown). The spike in dissolved Fe lasted approximately 40 days. During this time, the dissolved uranium concentration in many of the monitoring wells dropped from $1.0 \mu \mathrm{M}$ to below $0.2 \mu \mathrm{M}$, with the lowest concentrations below the drinking water standard of $0.137 \mu \mathrm{M}$, suggesting iron reducing bacteria may also be using uranium as a terminal electron acceptor. Unfortunately, there is no direct evidence as to which bacteria are utilizing uranium, since respiration is a dissimilatory process. Therefore, our efforts have focused on elucidating the microbes that are assimilating acetate since acetate loss is associated with decreases in uranium concentration in the field (Fig. 2).

SIP Measurements. Stable isotope probing experiments were used to ascertain the bacteria 
responsible for the acetate uptake at Rifle, on different particle size fractions. The 3 size fractions produced high molecular weight genomic DNA when extracted from the 1-24 day incubations, indicating there was a migration of bacteria from the soil/fines to the aqueous phase in each microcosm, since the groundwater had been filter sterilized. However, the planktonic phase generally had the lowest concentration of bacterial genomic DNA while the "fines" had the highest concentration (data not shown). When this genomic DNA was placed in a $\mathrm{CsCl}$ gradient with ${ }^{13} \mathrm{C}$ archaeal carrier DNA, it was possible to profile the bacterial SSU genes that were present $\left({ }^{12} \mathrm{C}\right.$ labeled $)$ and active $\left({ }^{13} \mathrm{C}\right.$ labeled). An example of SIP-TRFLP profiles is shown in figure 3, containing biological replicates for each phase at each time point. Each biological replicate is an independent ${ }^{13} \mathrm{C}$ incubation, extraction, amplification, and profile. Excellent agreement was observed between the active profiles from all biological replicates. The fingerprints indicate specific enrichment in particular peaks in the active fractions compared to the resident fraction in most profiles. For example, the active planktonic $(0.2-8.0 \mu \mathrm{m})$ fraction had higher 187 and 277 peaks, the active fines $(>8.0 \mu \mathrm{m})$ demonstrated an increase in peak area for the 59, 163, 164, and 212 bp peaks, and active coarse sand profiles illustrated a near complete elimination of the 176, 187, 210, 212, and 273 bp peaks compared with the planktonic and fines fraction and an increase in the 235 and 277 bp peak areas. The terminal fragment 277 was present in all active and resident fractions from the various phases. When observing a single time point in the incubation, the ${ }^{12}$ C-resident populations were highly similar in all phases collected from the microcosms (supplemental figure 3). For example, all resident profiles from these samples contained the 166, 206, 273, and 277 bp peaks that dominated the overall community fingerprint. In contrast, the active profiles demonstrated differences in the microorganisms utilizing acetate in the various phases.

Phylogenetic Identification of Active Bacteria. To identify the various TRFLP peaks within the active fraction, clone library analysis of SSU genes and phylogenetic tree re-construction were performed. The results are presented in figure 4. Many of the TRFLP peaks (173, 191, 187, 206, 210 bp) were Geobacter-like clones. While the 212 bp TRF matched Geobacter bemedjiensis. The SSU 
gene associated with the 166 bp peak was an $\alpha$-Proteobacteria with closest matches to environmental clones from a deep coal seam in Japan (accession number AB294270), and a North Sea oil field seawater injection system (EU330917). The ribosomal RNA gene associated with the 235 bp TRFLP peak was closely related to Dechloromonas sp. JJ (99\% identity) and the 277 bp peak matched Acinetobacter sp. ND12. Finally, clones corresponding to the 164 and 273 bp peaks were not represented in the SSU library when screening over 200 colonies.

Bacterial Activity Associated with Different Phases. To assess whether these various bacteria have a preference for being particle associated or planktonic during DNA synthesis using ${ }^{13} \mathrm{C}$ acetate, the relative proportion of the specific groups to the overall profiles was calculated (figure 5). This was accomplished by first normalizing all profiles to a single total area, adjusting the area for each peak (TRF), and than determining the contribution of those specific TRFs to the overall community profile. It can be seen from this analysis that Geobacter-like ${ }^{13} \mathrm{C}$ signal is generally higher in the planktonic phase and lower in the fines or the coarse sands for the pre-acetate field treatment samples (DO2 and DO3). In contrast, the $\alpha$-Proteobactium, 166 bp, appears to be more active on solid surfaces when compared to the groundwater phase. The Acinetobacter sp. was active on all fractions, but seems to have the greatest response in the fines. The Dechloromonas was predominantly seen in the later time points and had the highest signal on sediments. In the post- -stimulation samples (figure 6), there was no detectable $\alpha$ Proteobactium ${ }^{13} \mathrm{C}$ acetate associated DNA synthesis activity in either P101 or P102. A strong Geobacter-like signal was observed in the fines and sand phase from the shallow P101 sample. However, the deeper P101 sample indicated virtually no activity from any of the groups active in prestimulation samples. The P102 samples were generally less active for Geobacter and Acinetobacter when compared with the pre-stimulation samples, with the exception of the fines fraction from the deepest sample for the longest time point. For the P101 and 102 samples, most of the ${ }^{13} \mathrm{C}$ DNA signal is seen in peaks 149, 176, 273, 294 (data now shown). These TRF peaks were not represented in the clone library created from the pre-acetate field injection SIP incubations and presumably are related to sulfate- 
reducing populations since levels of FeII generally decline after 20 days of acetate amendment (Fig. 2).

Relevance to other studies of uranium contaminated sites. The concept that DNA containing different stable isotopes could be separated on a cesium chloride gradient had been demonstrated in early research on the mechanism of DNA replication (14). Other investigators have utilized stable isotopic methods to identify active bacteria in a field setting experiencing uranium reduction. For example, Chang et al. amended Bio-Sep beads with ${ }^{13} \mathrm{C}$-acetate at the Rifle site and incubated for 30days to detect different bacteria in iron supplemented and control samples by DGGE (15). The authors present different banding patterns for wells samples M03, M08, and M13 with a slight increase in band intensity for a Desulfobacter and a Geobacter-like OTU in ${ }^{13} \mathrm{C}$ amended samples. However, many of the DGGE bands were also present in the controls and this result casts doubt on the specific enrichment on ${ }^{13} \mathrm{C}$ acetate after the prolonged incubations due to cross feeding issues. Furthermore, the authors report some samples did not have visible ${ }^{13} \mathrm{C}$ bands in their cesium gradients with portions of the gradient collected at the same height as laboratory control gradient. Although this has been a common practice for many SIP incubations, it has been shown that ethidium bromide:DNA ratio can profoundly influence buoyant density (16) and there is no guarantee that an invisible environmental ${ }^{13} \mathrm{C}$ band will sediment at the same position as a visible laboratory ${ }^{13} \mathrm{C}$ control band with a much higher DNA concentration. In a comparable study, Burkhold et al., investigated ${ }^{13} \mathrm{C}$-ethanol and ${ }^{13} \mathrm{C}$-lactate incorporation in soil from Thuringia, Germany (17). In this report, incubations lasted 14 and 34 days and ${ }^{13} \mathrm{C}$ incorporation was assessed by collecting gradient fractions. The authors describe a single DNA peak at a density range of 1.52-1.62 (rather than 2 peaks) and it appears that 12 fractions were collected. TRFLP and clone library analysis was performed on half of these fractions and the results indicated detection of PCR product in fractions 6 and 7 for the 2 week incubation and in nearly all fractions after a 1 month incubation for both electron donors. Although the direction of ${ }^{13} \mathrm{C}$ enrichment is indicated in the TRFLP profiles, it is unclear which fraction corresponds to the peak in DNA concentration. Furthermore, there is no mention of ${ }^{12} \mathrm{C}$ ethanol or ${ }^{12} \mathrm{C}$ lactate controls to ensure that any PCR product 
detected in the gradients actually correspond to ${ }^{13} \mathrm{C}$ substrate addition.

In contrast to these other studies of uranium contaminated sites, our gradients always have clearly defined ${ }^{12} \mathrm{C}$ and ${ }^{13} \mathrm{C}$ bands due to the use of archaeal carrier DNA. In addition, we performed ${ }^{12} \mathrm{C}$ acetate amendment controls to ensure that any PCR detected in the ${ }^{13} \mathrm{C}$ carrier band only resulted from ${ }^{13} \mathrm{C}$ acetate addition. This approach allows for the unambiguous identification of the ${ }^{12} \mathrm{C}$ and ${ }^{13} \mathrm{C}$ fractions, ensures the SIP procedure is detecting heavy labeled DNA, and significantly shortens the time necessary to detect a ${ }^{13} \mathrm{C}$ signal from the incubations (13). The TRFLP analysis indicates a strong fluorescent signal is observed in all our profiles (Figure 3) and a distinct enrichment is observed for specific peaks when compared with the ${ }^{12} \mathrm{C}$ [resident] bacterial community. For example, the 187 and 277 peaks (Geobacter-like) are nearly undetectable in the resident population for the planktonic and fines fraction, but are greatly enhanced in the overall active profile. Selective enrichment along with a persistence and increase of specific OTUs in the ${ }^{13} \mathrm{C}$ fraction during time course incubations has been proposed as sufficient evidence for specific labeling of community members by ${ }^{13} \mathrm{C}$ substrates in SIP incubation (18).

Overall, our Winchester findings replicated the earlier results of Geobacter-like sequences being enriched in the groundwater phase while uranium reduction occurred $(1,2)$. However, different Geobacter-like SSU genes were identified with respect to the prior studies and most of the initial acetate utilization by Geobacter-like SSU genes appears to be concentrated on the "planktonic" fraction. This result is surprising, given that nearly identical microbial populations exist on the sand, in the water, and on the fines and presumably acetate is (Fig. 3). One explanation for this data would be that many of the bacteria are capable of transporting acetate into their cells, but only those bacteria associated with terminal electron acceptors are capable of ATP formation, DNA synthesis, and growth.

Another finding from the initial SIP experiments on pre-stimulation samples was the smaller peak area in the ${ }^{13} \mathrm{C}$ band by the Geobacter-like organisms as compared to the $\alpha$-Proteobactium (166 bp) and the Acinetobacter sp. peaks in the earliest time points or the shallower samples. Interestingly, many of 
the ${ }^{12} \mathrm{C}$ profiles indicate that the Geobacter-like organisms are present and in high abundance in the many of size fractions. This finding suggests that in our pre-stimulation samples, microorganisms that use high energy, soluable electron acceptors (such as nitrate) may be able to process the carbon from acetate into newly synthesized DNA faster than the bacteria that require solid electron acceptors (such as iron) or lower energy soluable electron acceptors (such as sulfate or uranium). Presumably, after the oxygen/nitrate become depleted, the Geobacter-like microbes persist in the system and later come to dominate the acetate utilization signal. This is exemplified by the 121, 187, 206, and 210 TRFLP peaks, which take up a significant amount of ${ }^{13} \mathrm{C}$ and are all Geobacter-like sequences. It is also possible the Geobacter-like microorganisms may leave the solid phase when saturating conditions are encountered, accumulate electron donor such as acetate, but have to return to the solid phase to complete electron transfer and commence DNA synthesis. Additionally, this competition for acetate as an electron donor may be what is leading to the approximately 20-day lag in uranium reduction that is seen at the Rifle site (Fig. 2).

However, after the in-field acetate addition, the a-Proteobacterial peak disappears from the SIPTRFLP profiles and the Geobacter-like peaks increase in area on the solid surfaces. Likewise, the Acinetobacter sp., and the Dechloromonas sp. JJ persist on the solid phases as well, indicating that these surfaces are providing the only remaining electron acceptors for these groups in the microcosm enrichments. It would be interesting to see whether the "fines" or coarse sand size fraction contains the goethite and phyllosilicates that are implicated in iron reduction by bacteria at various Dept. of Energy sites $(19,20)$ after field biostimulation. In conclusion, numerous bacteria are capable of acetate utilization at the Rifle, CO IFC site. This finding will be important for addressing uncertainties in reactive/transport modeling at the Rifle field site with respect to the microorganisms assumed to be consuming most of the injected acetate and to improve the conceptualization of transitions between iron-reducing and sulfate-reducing microorganisms (21). Initially, non- Geobacter-like microbes are responsible for most of the acetate uptake signal. However, with time, Geobacter-like organisms come 
to dominate the groundwater during acetate stimulation in situ and become a major acetate uptake signal on the solid phase fractions (figures 5 and 6). Perhaps there are other electron donors that can provide a quicker stimulus to these microorganisms or other specific bacterial populations and induce uranium reduction in a faster manner.

ACKNOWLEDGMENT. The authors thank Dick Dayvault, Mike Wilkins, and Aaron D. Peacock for their assistance in the field. The Rifle IFC is funded by the Environmental Remediation Sciences Program, Biological and Environmental Research, Office of Science, U.S. Department of Energy. The Pacific Northwest National Laboratory is operated by Battelle Memorial Institute for the U. S. Department of Energy (Contract Number DE-AC06-76RLO-1830). The Lawrence Berkeley National Laboratory (LBNL) is operated for the U.S. Department of Energy by the University of California under contract DE-AC02-05CH11231, with funding for the LBNL contributions derived equally from the Rifle IFRC and LBNL Science Focus Area Sustainable Systems research programs. 


\section{FIGURES.}

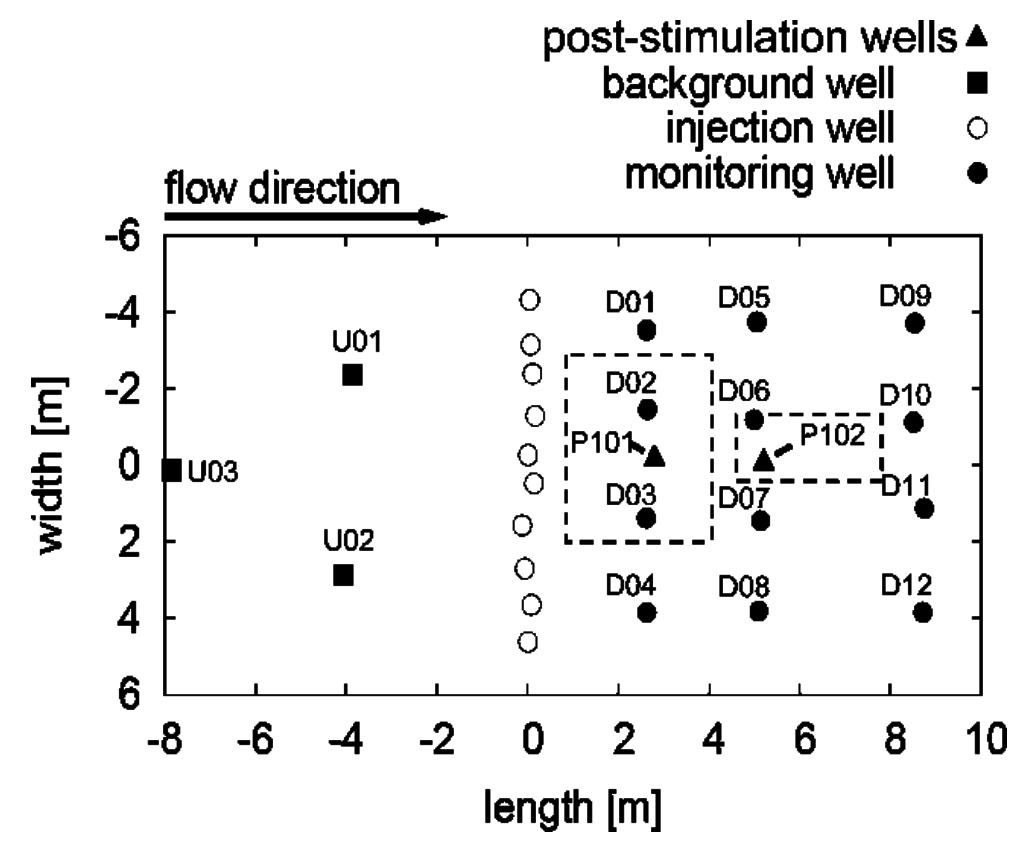

Figure 1. Schematic of Winchester gallery showing the location/spacing of the wells. The dashed boxes indicate those wells sampled for SIP measurements. 

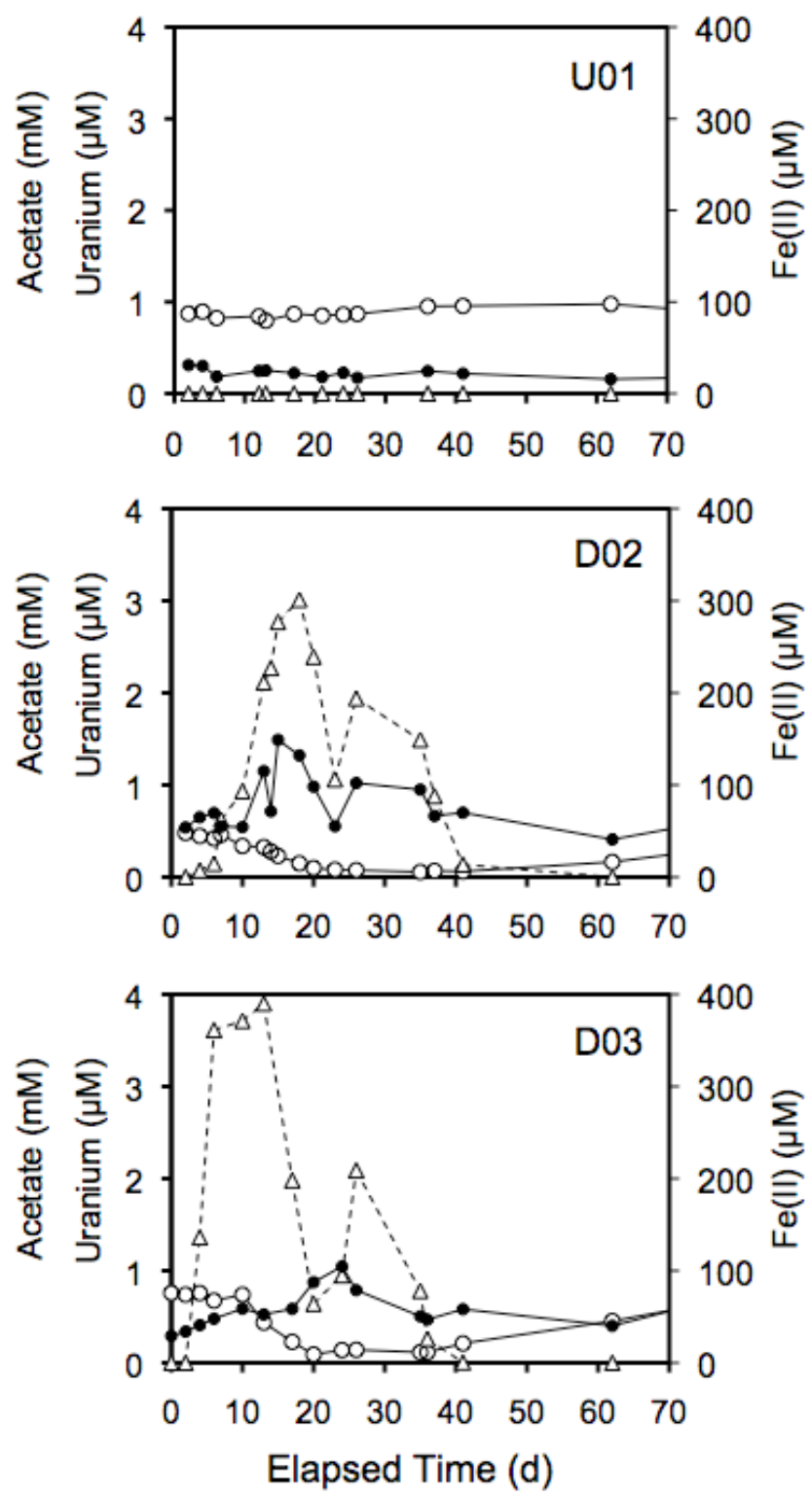

Figure 2. Time course of acetate (open triangles), Fe II (closed circles), and uranium concentrations (open circles) during field addition of $10 \mathrm{mM}$ acetate. 


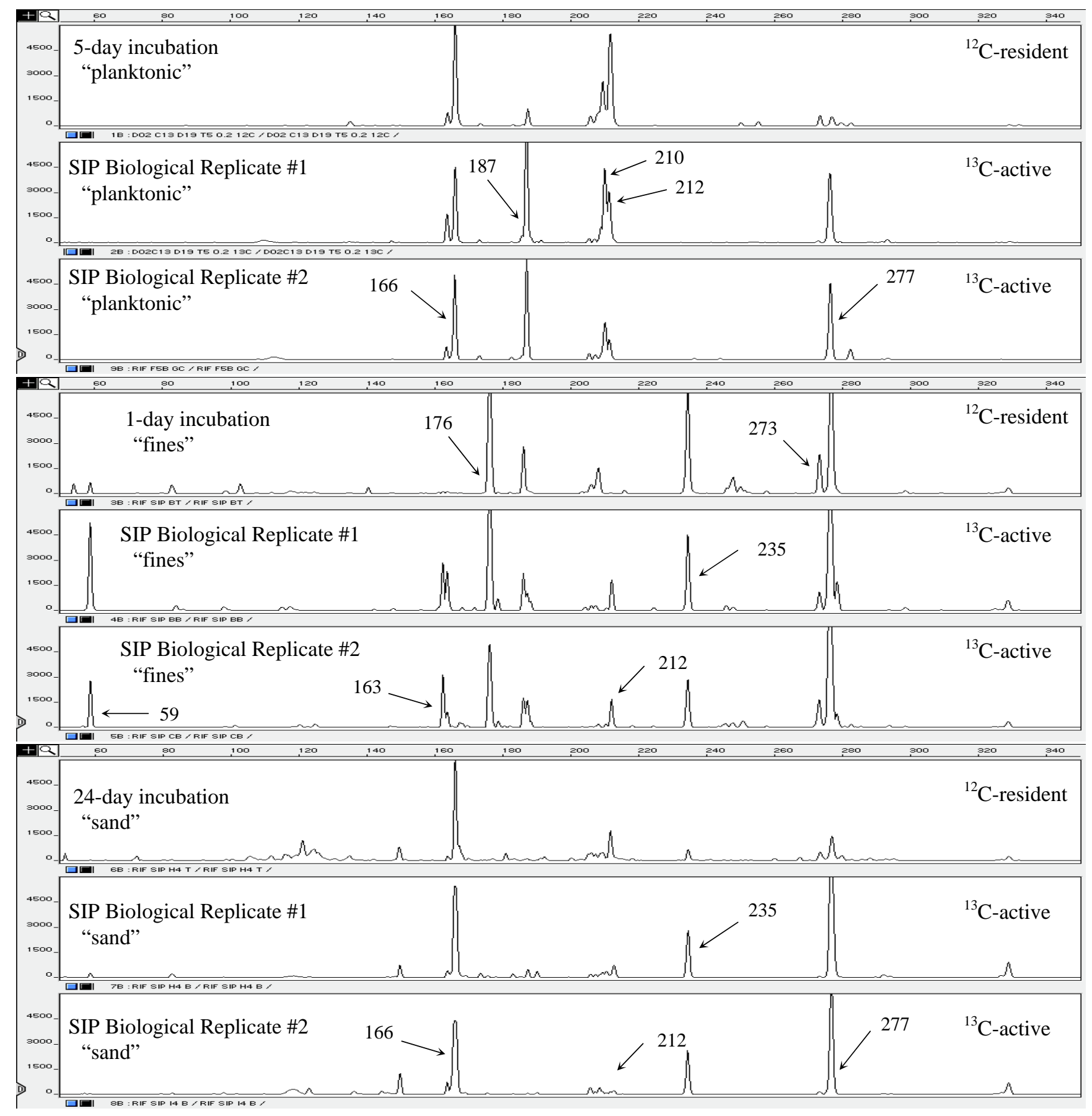

Figure 3. SIP-TRFLP fingerprints demonstrating biological replicates at 1,5 , and 24 day time points with the resident $\left({ }^{12} \mathrm{C}\right)$ and active $\left({ }^{13} \mathrm{C}\right)$ bacterial populations in the planktonic, fines, and sand phases indicated. 


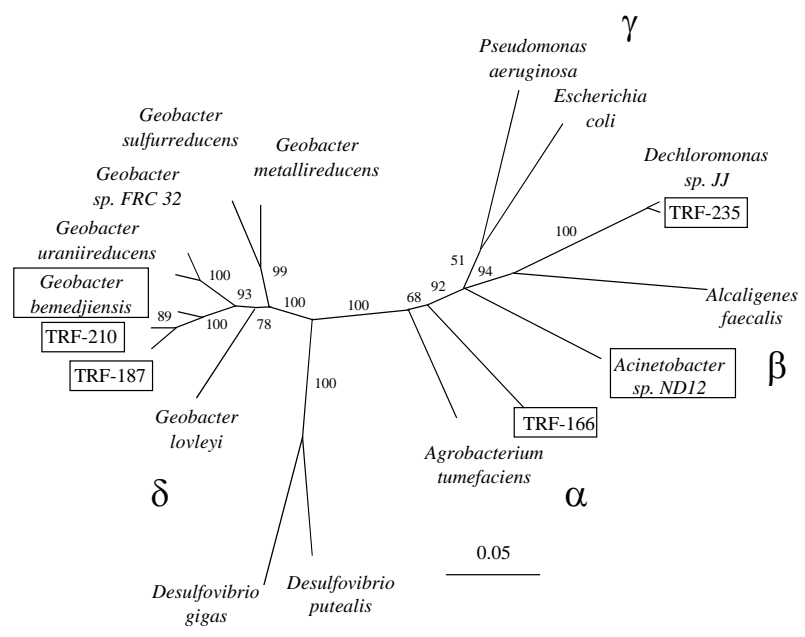

Figure 4. Phylogentic tree reconstruction of SSU clones related to major peaks in the SIP profiles (Genbank accession \# GU943742-45). Both Geobacter bemedjiensis(TRF-212) and Acinetobacter sp. ND12 (TRF-277) were also detected. Major subdivsions of the Proteobacteria are indicated. 


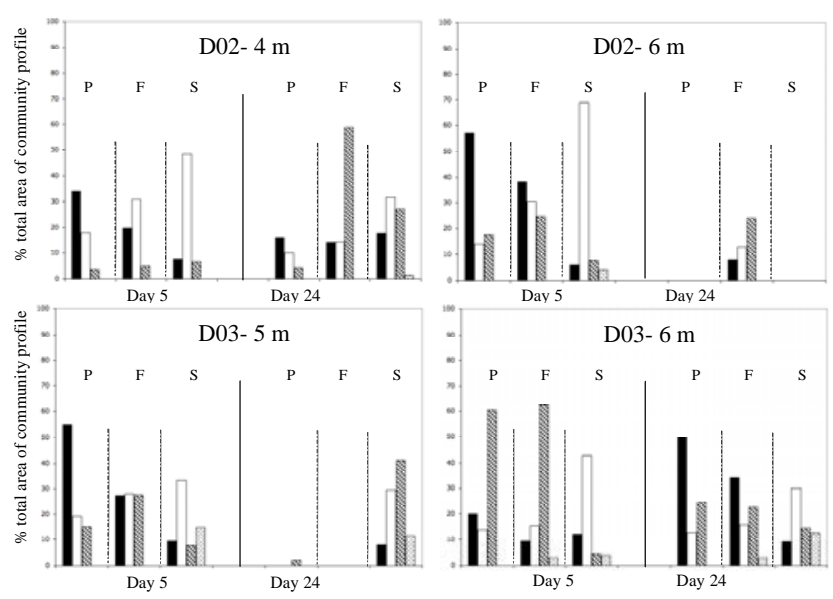

Figure 5. Summary graphs indicating relative proportion of ${ }^{13} \mathrm{C}$ profiles for the major TRFLP peaks before field-scale acetate addition [DO2, DO3]: Geobacter-like group (black), 166 bp (white), Acinetobacter sp. (diagonal), Dechloromonas sp. (hashed). 


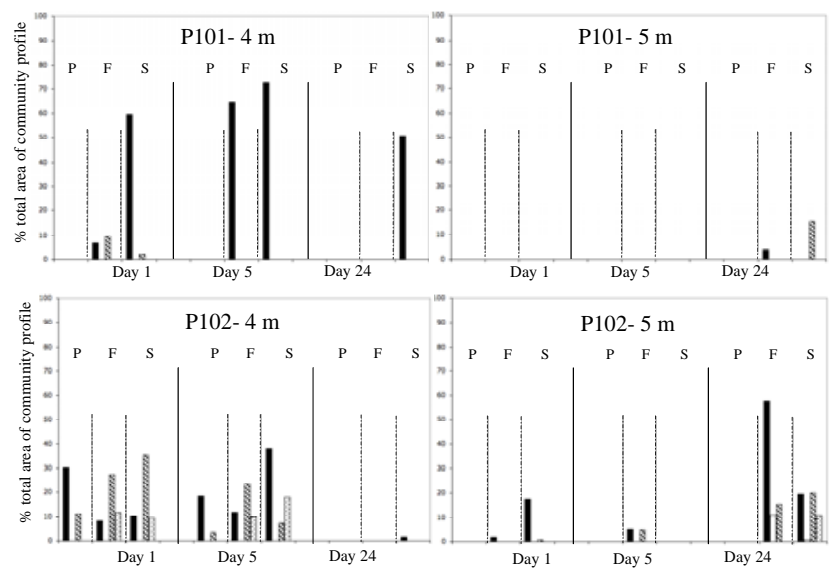

Figure 6. Summary graphs indicating relative proportion of ${ }^{13} \mathrm{C}$ profiles for the major TRFLP peaks after field-scale acetate addition [P101, P102]: Geobacter-like group (black), 166 bp (white), Acinetobacter sp. (diagonal), Dechloromonas sp. (hashed). 


\section{REFERENCES.}

(1) Anderson, R. T; Vrionis, H. A.; Ortiz-Bernad, I.; Resch, C. T.; Long, P. E.; Dayvault, R.; Karp, K.; Marutzky, S.; Metzler, D. R.; Peacock, A.; et al., Stimulating the In Situ Activity of Geobacter Species To Remove Uranium from the Groundwater of a Uranium-Contaminated Aquifer. Appl. Environ. Microbiol. 2003, 69, 5884-5891

(2) Vrionis, H. A.; Anderson, R. T.; Ortiz-Bernad, I.; O’Neill, K. R.; Resch, C. T.; Peacock, A. D.; Dayvault, R.; White, D. C; Long P. E.; Lovley, D. R. Microbiological and Geochemical Heterogeneity in an In Situ Uranium Bioremediation Field Site. Appl. Environ. Microbiol. 2005, 71, 6308-6318

(3) Boschker, H. T. S.; Nold, S. C.; Wellsbury, P.; Bos, D.; de Graaf, W.; Pel, R.; Parkes, R. J.; Cappenburg, T. E. Direct linking of microbial populations to specific biogeochemical processes by [13]C-labeling of biomarkers. Nature. 1998, 392, 801-805.

(4) Boschker, H. T. S.; Middelburg, J. J. Stable isotopes and biomarkers in microbial ecology. FEMS Micro. Ecol. 2002, 40, 85-95.

(5) Roslev, P.; Iversen, N.; Henriksen. K. Direct fingerprinting of metabolically active bacteria in environmental samples by substrate specific radiolabeling and lipid analysis. J. of Micro. Meth. 1998, 31, 99-111.

(6) Radajewski, S.; Ineson, P.; Parekh, N.; Murrell. J. C. Stable-isotope probing as a tool in microbial ecology. Nature. 2000, 403, 646-649.

(7) Whiteley, A. S.; Manefield, M.; Lueders, T. Unlocking the 'microbial black box' using RNAbased stable isotope probing technologies. Cur. Opin. in Biotech. 2006, 17, 67-71.

(8) Friedrich, M. W. Stable-isotope probing of DNA: insights into the function of uncultivated 
microorganisms from isotopically labeled metagenomes. Cur. Opin. in Biotech. 2006, 17, 59-66.

(9) Madsen, E. L. The use of stable isotope probing techniques in bioreactor and field studies on bioremediation. Cur. Opin. in Biotech. 2006, 17, 92-97.

(10) Willams, K, H.; Long, P. E.; Davis, J. A.; Wilkins, M. J.; N’Guessan, A. L; Yang, L; Newcomer, D.; Spane, F. A.; Kerkhof, L. J.; McGuinness, L.; Dayvault, R.; Lovley. D. R. Acetate availability and its influence on sustainable bioremediation of uranium-contaminated groundwater. Geomicrobiology J. 2010. In Press

(11) Hyndman, D.; Dybas, M.; Forney, L.; Heine, R.; Mayotte, T.; Phanikumar, M.; G. Tatara, et al., Hydraulic Characterization and Design of a Full-Scale Biocurtain. Groundwater. 2000, 38, 462-474.

(12) McGuinness, L.; Salganik, M.; Vega, L.; Pickering, K. D.; Kerkhof. L. J. Replicability of bacterial communities in denitrifying bioreactors as measured by PCR/T-RFLP analysis. Environ. Sci. Technol. 2006, 40, 509-515.

(13) Gallagher, E.; McGuinness, L.; Phelps, C.; Young, L. Y.; Kerkhof. L. J. ${ }^{13}$ C-carrier DNA shortens the incubation time needed to detect benzoate-utilizing denitrifying bacteria by stable-isotope probing. Appl. Environ. Microbiol. 2005, 71, 5192-5196.

(14) Meselson, M.; Stahl. F. W. The replication of DNA. Cold Spring Harb Symp Quant Biol. 1958, 23, 9-12.

(15) Chang Y.J.; Long P.E.; Geyer R.; Peacock, A. D.; Resch, C. T.; Sublette, K.; Pfiffner, S.; Smithgall, A.; Anderson, R. T.; Vrionis, H. A; et al. Microbial incorporation of C-13-labeled acetate at the field scale: Detection of microbes responsible for reduction of U(VI). Environ. Sci. Technol. 2005, 39, 9039-9048

(16) Gallagher, E.; Young, L. Y.; McGuinness, L.; Kerkhof, L. J. Detection of 2,4,6-Trinitrotoluene- 
Utilizing Anaerobic Bacteria by ${ }^{15} \mathrm{~N}$ and ${ }^{13} \mathrm{C}$ Incorporation. Appl. Environ. Microbiol. 2010, 76, 16951698

(17) Burkhardt, E-M.; Akob, D. M.; Bischoff, S.; Sitte, J.; Kostka, J. E.; Banerjee, D.; Scheinost, A. C.; Kusel, K. Impact of Biostimulated Redox Processes on Metal Dynamics in an Iron-Rich Creek Soil of a Former Uranium Mining Area. Environ. Sci. Technol. 2010, 44, 177-183

(18) Leuders, T.; Manefield, M.; Friedrich. M. W. Enhanced sensitivity of DNA- and rRNA-based stable isotope probing by fractionation and quantitative analysis of isopycnic centrifugation gradients. Environ. Microbiol. 2004, 6, 73-78.

(19) Kukkadapu, R. K.; Zachara, J. M.; Fredrickson, J. K.; McKinley, J. P.; Kennedy, D. W.; Smith, S. C.; Dong, H. Reductive biotransformation of Fe in shale-limestone saprolite containing Fe(III) oxides and Fe(II)/Fe(III) phyllosilicates. Geochimica et Cosmochimica Acta. 2006, 70, 3662-3676

(20) Stucki, J. W.; Lee, K.; Goodman, B. A.; Kostka. J. E. Effects of in situ biostimulation on iron mineral speciation in a sub-surface soil. Geochimica et Cosmochimica Acta. 2007, 71, 835-843

(21) Yabusaki, S. B.; Fang, Y.; Long , P. E.; Resch , C. T.; Peacock, A. D.; Komlos, J.; Jaffe, P. R.; Morrison, S. J.; Dayvault, R. D.; White, D. C.; Anderson, R. T. Uranium removal from groundwater via in situ biostimulation: Field-scale modeling of transport and biological processes. $J$. of Contaminant Hydrology. 2007, 93, 216-235

SYNOPSIS TOC: Soil-associated microorganisms display a preference when utilizing ${ }^{13} \mathrm{C}$ acetate for being in groundwater or different particulate phases at the Rifle, CO, Integrated Research Site. 


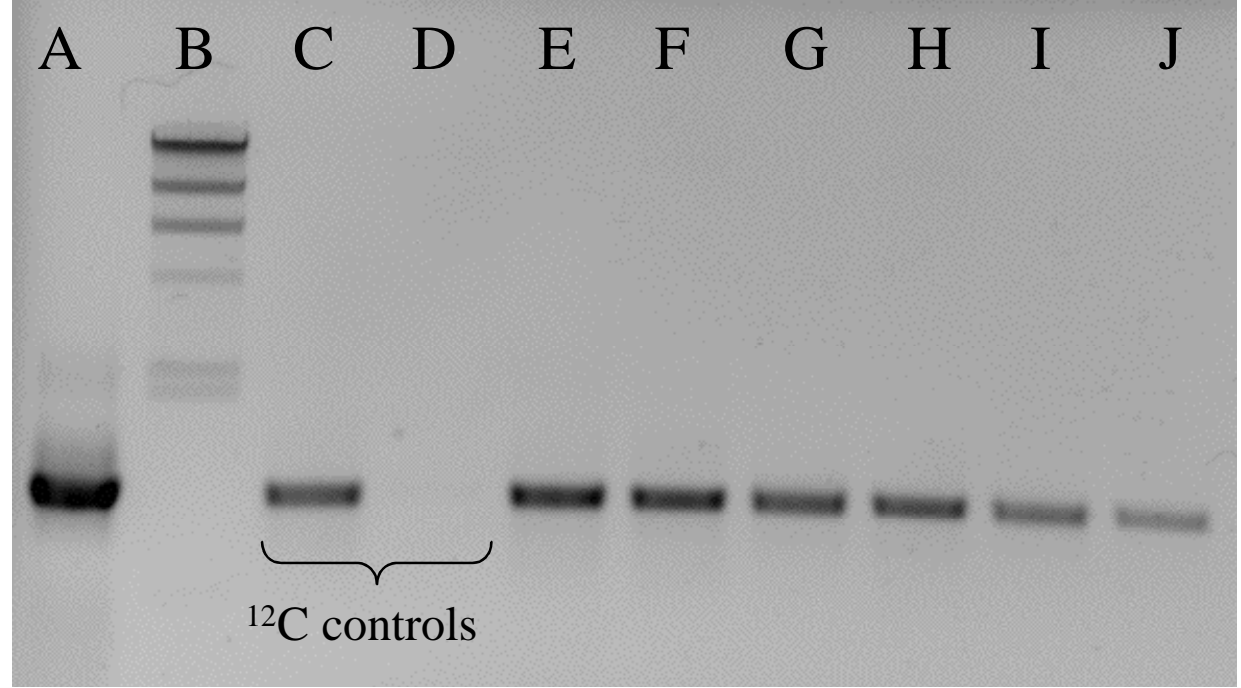

Supplemental Figure 1. PCR amplification of ${ }^{12} \mathrm{C}$ (resident) and ${ }^{13} \mathrm{C}$ (active) bacteria from well DO3 (6m) after 24 d incubation. Lanes are: A) PCR + control B) Lambda HinDIII marker C) ${ }^{12} \mathrm{C}$ acetate amended planktonic fraction resident D) ${ }^{12} \mathrm{C}$ acetate amended planktonic fraction active E) ${ }^{13} \mathrm{C}$ acetate amended planktonic fraction resident F) ${ }^{13} \mathrm{C}$ acetate amended planktonic fraction active $\left.\mathrm{G}\right){ }^{13} \mathrm{C}$ acetate amended fines fraction resident $\mathrm{H}$ ) ${ }^{13} \mathrm{C}$ acetate amended fines fraction active I) ${ }^{13} \mathrm{C}$ acetate amended sand fraction resident $\mathrm{J})^{13} \mathrm{C}$ acetate amended fines fraction active. 


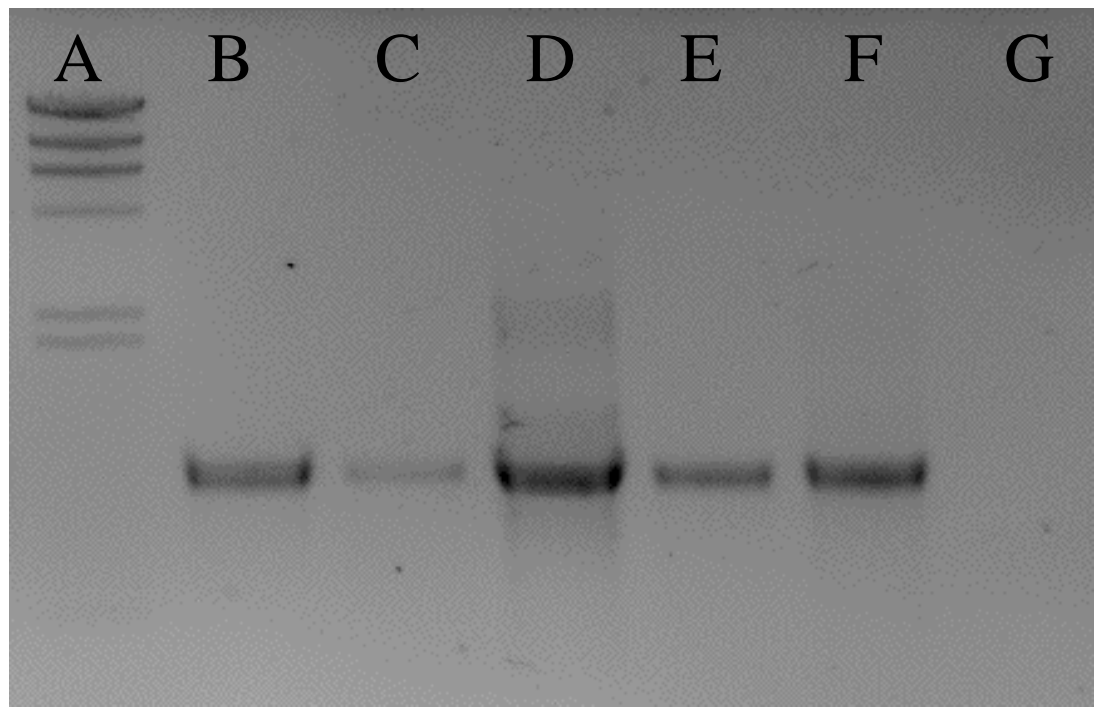

Suppmental Figure 2. PCR amplification of ${ }^{12} \mathrm{C}$ (resident) and ${ }^{13} \mathrm{C}$ (active) bacteria from well P102 (6m) after $1 \mathrm{~d}$ incubation. Lanes are: A) Lambda HinDIII marker B) ${ }^{13} \mathrm{C}$ acetate amended planktonic fraction resident C) ${ }^{13} \mathrm{C}$ acetate amended planktonic fraction active $\left.\mathrm{D}\right){ }^{13} \mathrm{C}$ acetate amended fines fraction resident E) ${ }^{13} \mathrm{C}$ acetate amended fines fraction active $\mathrm{F}$ ) ${ }^{13} \mathrm{C}$ acetate amended sand fraction resident $\mathrm{G})^{13} \mathrm{C}$ acetate amended fines fraction active. 


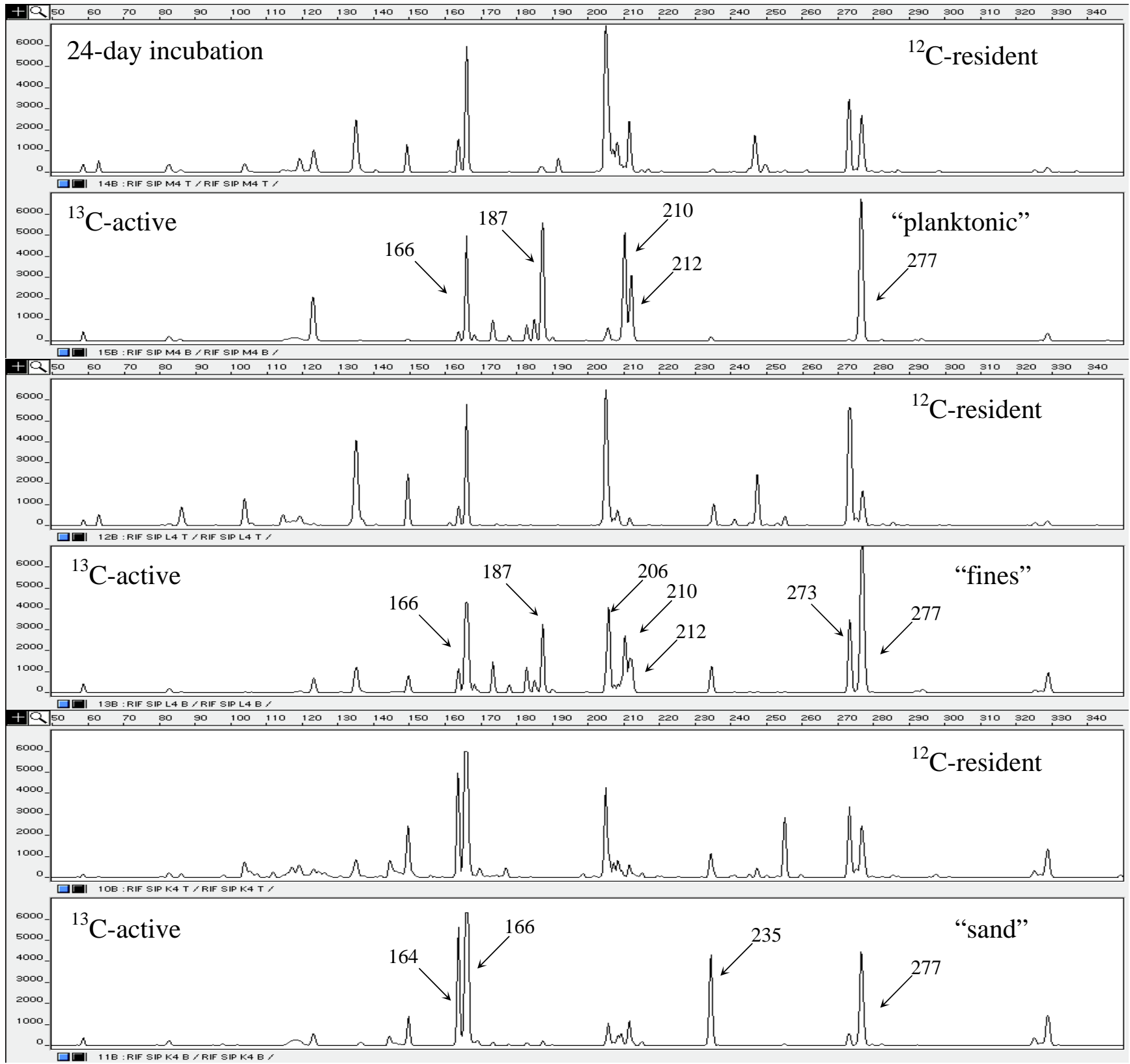

Suppmental Figure 3. Example of TRFLP fingerprints from SIP experiment from 24 day incubation showing both the resident $\left({ }^{12} \mathrm{C}\right)$ and active $\left({ }^{13} \mathrm{C}\right)$ bacterial population in the planktonic, fines, and sand phases. 


\section{DISCLAIMER}

This document was prepared as an account of work sponsored by the United States Government. While this document is believed to contain correct information, neither the United States Government nor any agency thereof, nor the Regents of the University of California, nor any of their employees, makes any warranty, express or implied, or assumes any legal responsibility for the accuracy, completeness, or usefulness of any information, apparatus, product, or process disclosed, or represents that its use would not infringe privately owned rights. Reference herein to any specific commercial product, process, or service by its trade name, trademark, manufacturer, or otherwise, does not necessarily constitute or imply its endorsement, recommendation, or favoring by the United States Government or any agency thereof, or the Regents of the University of California. The views and opinions of authors expressed herein do not necessarily state or reflect those of the United States Government or any agency thereof or the Regents of the University of California. 